\title{
GENETIC ENGINEERING MATERIALS BANK OF THE NATIONAL CENTER FOR BIOTECHNOLOGY
}

\author{
Sarsen A. ${ }^{1,2}$, Saginova M. ${ }^{1,2}$, Mukanov B. ${ }^{1,2}$, Aktayeva S. $^{1,2}$, Akishev Zh. ${ }^{1}$, \\ Mussakhmetov A. ${ }^{1}$, Kiribayeva A. ${ }^{1}$, Baltin K. ${ }^{1}$, Silayev D. ${ }^{1}$, Khassenov B. ${ }^{1}$ \\ ${ }^{1}$ National center for biotechnology \\ 13/5, Kourgalzhyn road, Nur-Sultan, 010000, Kazakhstan \\ ${ }^{2}$ L.N.Gumilyov Eurasian National University \\ Satpayev str., 2, Nur-Sultan, 010000, Kazakhstan \\ khassenov@biocenter.kz.
}

\begin{abstract}
For the development of science-intensive technologies in biology, biotechnology and medicine, it is necessary to store valuable DNA samples: genes of enzymes, antigens, proteins for various purposes, and DNA loci in a depository. Storing DNA is inexpensive, and having such a depository will reduce the time spent on research in basic and applied science.

The genetically engineered materials bank has been formed at the National center for biotechnology. Now, the bank has 88 samples of cloned genes of enzymes, antigens, proteins and diagnostically significant loci. Plasmid vectors with cloned genes are stored at a temperature $-\mathbf{2 0}^{\circ} \mathrm{C}$. Besides competent cells of Escherichia coli strain DH5a were transformed with vectors and recombinant strains were isolated. Recombinant strains carrying the required plasmid vectors are stored for cryopreservation at a temperature $\mathrm{80}^{\circ} \mathrm{C}$.
\end{abstract}

Key words: biobank, DNA, strain, gene, protein.

For the development of science-intensive technologies in biology, biotechnology and medicine, it is necessary to store valuable DNA samples: genes of enzymes, antigens, proteins for various purposes, and DNA loci in a depository. Storing DNA is inexpensive, and having such a depository will reduce the time spent on research in fundamental and applied science. An example of a working collection is the non-profit organization Addgen, which is the largest depository of plasmids between laboratories and research centers around the world and has more than 90 thousand plasmids [1].

The genetically engineered materials bank has been formed at the National center for biotechnology in Science-Technical Program O.0809 "Organization of a biobank for microorganisms, cell cultures, genomic and genetically engineered materials for a preservation of a biodiversity and provision of a basis of biotechnology resources"

The bank of genetically engineered materials is aimed at storing and replenishing the bank with valuable genetic material, especially genes. The bank is responsible for receiving, storing, processing and issuing the provided genetic material.

Now, the bank has 88 samples of cloned genes of enzymes, antigens, proteins and diagnostically significant loci. Some of the presented samples are the result of experimental studies [2-6], others are new samples still not characterized. Storage of genetic material is carried out in plasmid vectors, freely replicating in laboratory strains of Escherichia coli.

The bank stores genes of enzymes for various functional purposes. In particularly, DNA and RNA depending polymerases genes from Thermus aquaticus, Thermus thermophilus, Pyrococcus furiosus, Geobacillus stearothermophilus Escherichia coli, HIV; $\alpha$-amylases from Bacillus licheniformi sBacillus velezensis, Bacillus subtilis; proteases from Bacillus 
licheniformis, Bostaurus, Camelus bactrianus Caprahircus, $\beta$-galactosidase from Lactobacillus plantarum, Streptococcus thermophilus, phosphatases from Escherichia coli, Bacillus licheniformis; DNA repair enzymes from Helicobacter pylori, Mycobacterium tuberculosis, Staphylococcus aureus, Escherichia coli, and genes of others enzymes.

The genes of antigens in the bank, are represented with genes of: membrane proteins of Staphylococcus aureus, Streptococcussp. Treponema pallidum, Leptospirasp., Newcastle virus nucleocapcid, structure proteins of Bovine leucosis virus, Coronavirus SARS-CoV-2.

In the bank, there are human genes of:deglycaseDJ1 (Parkinson disease protein 7), interferon gamma (INF $\gamma$ ), granulocyte colony-stimulating factor (GCSF),pluripotency factors (Oct4, Nanog; Sox2 c-Myc),tumor markers (Her2, Ki67). The collection contains genes for fluorescent proteins used in scientific research.

For PCR typing and PCR diagnostics, DNA loci are required as positive controls and/or for working out the diagnostic protocol. For example, for the species identification of bacteria of the genus Lactobacillus, DNA loci were selected, cloned and deposited, which showed diagnostic value.

All genes are cloned into plasmid vectors, some of which are expression vectors and can be used to produce the target protein in bacteria or yeast. Plasmid vectors with cloned genes are stored at a temperature $-20^{\circ} \mathrm{C}$. Additionally, competent cells of Escherichia coli strain DH5 $\alpha$ were transformed with vectors and recombinant strains were isolated. Recombinant strains carrying the required plasmid vectors are stored for cryopreservation at a temperature $-80^{\circ} \mathrm{C}$. This option allows not only storing, but also simplifying the production of the gene. The bank is adjunction with new samples by National center for biotechnology

\section{Acknowledgments}

The work was supported by the Ministry of Education and Science of the Republic of Kazakhstan (Science-Technical Program O.0809, No.BR05236334).

\section{REFERENCES}

1. https://www.addgene.org/

2. Bhatt, K., et al., Molecular analysis of Bacillus velezensis KB 2216, purification and biochemical characterization of alpha-amylase. Int $J$ BiolMacromol, 2020, 2020.10.1016/j.ijbiomac.2020.08.205.

3. Mussakhmetov, A., et al., A transient post-translational modification of active site cysteine alters binding properties of the parkinsonism protein DJ-1. BiochemBiophys Res Commun., 2018, vol.504, no.1, pp. 328-333. https://pubmed.ncbi.nlm.nih.gov/32871125/

4. Tsien, R.Y., The green fluorescent protein. Ann Rev Biochem., 1998, vol. 67, pp. 50944.

5. Akishev Zh., Abeldenov S., Ramanculov E., Khassenov B. Expression of camel (Camelusbactrianus) and bovine (Bostaurus) chymosin in Pichia (Komagataella) pastoris. Journal of Biotechnology., 2017, vol.256S, pp.S73-S74. doi: 10.1016/j.jbiotec.2017.06.1050

6. Turgimbayeva, A. et al., Characterization of biochemical properties of an apurinic/apyrimidinic endonuclease from Helicobacter pylori. PLoS One, 2018, vol. 13, no. 8, pp. e0202232.

\section{ҰЛТТЫҚ БИОТЕХНОЛОГИЯ ОРТАЛЫҒЫНЫН ГЕНДІК-ИНЖЕНЕРЛІК МАТЕРИАЛДАР БАНКІ}

Сәрсен А., ${ }^{1,2}$ Сагинова М. ${ }^{1,2}$, Муканов Б. ${ }^{1,2}$, Актаева С. ${ }^{1,2}$, Акишев Ж. Мусахметов А. ${ }^{1}$, Кирибаева А. ${ }^{1}$, Балтин К. ${ }^{1}$, Силаев Д. ${ }^{1}$, Хасенов Б. ${ }^{1}$ 


\author{
${ }^{1}$ Ұлттық биотехнология ортальвы \\ Қорвалжын тас жоль, 13/5, Нұр-Сұлтан қ., 010000, Қазақстан \\ ${ }^{2}$ Л.Н.Гумилев атындавы Еуразия Ұлттық Университетті \\ Сәтпаев көшесі, 2, Нұр-сұлтан қ., 010000, Қазақстан \\ khassenov@biocenter.kz
}

Биология, биотехнология және медицина саласындағы ғылымды қажетсінетін технологияларды дамыту үшін ДНҚ-ның құнды үлгілерін: ферменттер гендерін, антигендерді, әртүрлі мақсаттағы ақуыздарды, локус ДНК-ны сақтауды жүзеге асыратын депозитарий қажет. ДНҚ-ны сақтау қымбат шара емес, сонымен бірге мұндай депозитарийдің болуы іргелі және қолданбалы маңызы бар зерттеулер жүргізуге кететін уақытты қысқартуға мүмкіндік береді.

Ұлттық биотехнология орталығында гендік-инженерлік материалдар банкі құрылды. Қазіргі уақытта банкте ферменттердің, антигендердің, ақуыздардың клондалған гендерінің және диагностикалық маңызы бар локустардың 88 үлгісі бар. Генетикалық материалды сақтау плазмид векторларында $-20^{\circ} \mathrm{C}$ температурада жүзеге асырылады. Сонымен қатар, вектормен трансформацияланған компетентті E.coli DH5a жасушалары бар. Қажетті плазмидтік векторларды тасымалдайтын рекомбинантты штаммдар $-80^{\circ} \mathrm{C}$ температурада криосақтануға салынған.

Негізгі сөздері: биобанк, ДНК, штамм, ген, ақуыз.

\title{
БАНК ГЕННО-ИНЖЕНЕРНЫХ МАТЕРИАЛОВ НАЦИОНАЛЬНОГО ЦЕНТРА БИОТЕХНОЛОГИИ
}

\author{
Сарсен А., ${ }^{1,2}$, Сагинова М.. ${ }^{1,2}$, Муканов Б. ${ }^{1,2}$, Актаева С. ${ }^{1,2}$, Акишев ж. ${ }^{1}$, \\ Мусахметов А. ${ }^{1}$, Кирибаева А. ${ }^{1}$, Балтин К. ${ }^{1}$, Силаев Д. ${ }^{1}$, Хасенов Б. ${ }^{1}$ \\ ${ }^{1}$ Национальный ичентр биотехнологии \\ Кургальжинское шоссе, 13/5, г.Нур-Султан, 010000, Казахстан \\ ${ }^{2}$ Евразийский Национальный Университет им.Л.Н.Гумилева \\ ул.Сатпаева, 2, г.Нур-Султан, 010000, Казахстан \\ khassenov@biocenter.kz
}

Для развития наукоемких технологий в области биологии, биотехнологии и медицины необходим депозитарий, в котором осуществлялось бы хранение ценных образцов ДНК: гены ферментов, антигенов, белков различного назначения, ДНК локусов. Хранение ДНК не является затратным мероприятием, но в тоже время, наличие такого депозитария позволит сократить время на проведение исследований фундаментального и прикладного значения.

В Национальном центре биотехнологии сформирован банк генно-инженерных материалов. На данный момент банк насчитывает 88 образцов клонированных генов ферментов, антигенов, белков и диагностически-значимых локусов. Хранение генетического материала осуществляется в плазмидных векторахпри температуре $20^{\circ}$ С. Дополнительно, векторами были трансформированы компетентные клетки E.coli DH5a. Рекомбинантные штаммы, несущие требуемые плазмидные вектора заложены на криосохранение при температуре $-80^{\circ} \mathrm{C}$.

Ключевые слова: биобанк, ДНК, штамм, ген, белок. 